IRA-International Journal of Education \& Multidisciplinary Studies

ISSN 2455-2526; Vol.05, Issue 03 (2016)

Pg. no. 161-165

Institute of Research Advances

http://research-advances.org/index.php/IJEMS

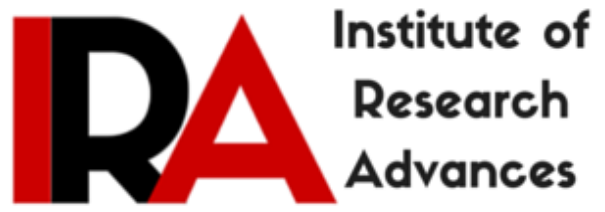

\title{
Analysis of Public Private Partnership Model with reference to Teacher Education Programme
}

\author{
Prerna Mandhyan \\ Assistant Professor \\ Seemanchal Minority B.Ed College, \\ Katihar (Bihar) - 854105, India.
}

Type of Review: Peer Reviewed.

DOI: http://dx.doi.org/10.21013/jems.v5.n3.p4

\section{How to cite this paper:}

Mandhyan, P. (2016). Analysis of Public Private Partnership Model with reference to Teacher Education Programme. IRA International Journal of Education and Multidisciplinary Studies (ISSN 2455-2526), 5(3), 161-165. doi:http://dx.doi.org/10.21013/jems.v5.n3.p4

(C) Institute of Research Advances

\section{(oc) EY-NC}

This work is licensed under a Creative Commons Attribution-Non Commercial 4.0 International License subject to proper citation to the publication source of the work.

Disclaimer: The scholarly papers as reviewed and published by the Institute of Research Advances (IRA) are the views and opinions of their respective authors and are not the views or opinions of the IRA. The IRA disclaims of any harm or loss caused due to the published content to any party. 


\section{ABSTRACT}

India is consisting largest system of teacher education in India. Besides the University Departments of education and their affiliated colleges there are a number of govt. and govt. aided institutions and self financing colleges and open universities who are engaged in teacher education. The present study analyse PPP model with reference to teacher education programme. Finally, the study examines and assesses the current status of public and private institutions in providing teacher training programmes. The study further probes different views on PPP model in pre-service teacher education programme.
\end{abstract}

Keywords: Public Private Partnership, Govt. Aided Institutions, Self Financing Colleges

Teacher education is a vital part of school education. It is the single most important factor for meeting quality parameters in schools. This sector is responsible for preparing teachers prior to entering the school system, and for continuous professional development of teachers who have entered the system. $45.34 \%$ of the 4.7 lakh teachers in the elementary (Class 1-8) school system have not studied beyond class 12 and a quarter of them have not studied beyond class 10 . Only $35 \%$ teachers are graduates, $12 \%$ post graduates; $0.4 \%$ have M.Phil./Ph.D. degree (Mehta, A.C. 2006). The failure to build sufficient teacher education institutions has been compounded by the induction of under-qualified and un-trained teachers into the school system, even while lakhs of graduates with B.Ed. remain unemployed outside the system. Quality issues in teacher education continue to remain a cause for concern.

Around 8 lakh teachers are prepared by around 8000 teacher education institutions (NCFTE, 2010) most of which are run by the private sector. The National Council for Teacher Education created in 1995 by a 1993 Act of Parliament has the mandate to achieve planned and coordinated development of teacher education system in the country, regulate and maintain norms and standards in TEIs. Till 1993, there were 633 TEIs in both private and government sectors. Since then, around 8000 TEIs have come into being prompting accusations of indiscriminate permissions being granted with accompanying steep fall in quality in teacher education quality and infrastructure. Two committees set up by the MHRD, the Sathyam Committee (2004) and Sudeep Bannerji committee (2007) have gone into issues of the open door policy of granting recognition to private TEIs resulting in substantial numbers of prospective teachers who write their exams and are awarded degrees without attending their course of study often for even a single day, unmindful of the reality that qualified teacher educators were simply not available. (Yasmeen, S., EducationWorld, 2008). While the Sathyam committee identified the routine bypassing of out of turn applications and inspection teams approving applications of promoters of questionable credibility, the Bannerji committee recommended that license and regulation functions of NCTE be eliminated from it and transferred to affiliating universities/SCERTs, and NCTE be transformed into a teacher training and pedagogy research organization.

\title{
Need of New Teacher Training Colleges
}

India has one of the largest systems of education. There are nearly 5.98 lakh primary schools, 76 lakhs elementary schools and 98 thousand high or higher schools in the country. In 200910 there were around 5.23 lakh teacher posts vacant under state quota with large inter state variations. Uttar Pradesh had the highest vacancy of 1.65 lakh teachers followed by West Bengal $(52,764)$, Bihar(51,074), Orissa(37,901), Chattishgarh $(34,985)$ and Rajasthan $(29,356)$. Estimates prepared by NUEPA and MHRD in 2009 showed that to implement the RTE Act recruitment of 5.1 lakh additional teacher posts have been sanctioned under the combine RTE SSA programme. Again, out of about 4.52 million teachers in the country nearly 3 million are teaching at the elementary level. A sizeable number of them are untrained or under training. One of the major problems confronting the states with large teacher vacancy and inadequacy of trained teachers is the inadequate number of the teacher training institutions and their annual intake capacity. 
Taking the whole school system together, this represents around $26.6 \%$ of teachers in the school system. The introduction of such large number of teachers in the school system provides challenges, but also a unique opportunity for qualitative improvement. Teacher education has taken on a special urgency. To prepare 9.73 lakh teachers, 22,500 teacher educators per year are required. The present institutional capacity is only 3775. An additional 19,000 teacher educators are urgently required (MHRD, TE-EFC, 2011).

The Rashtriya Madhyamik Shiksha Abhiyan (RMSA) launched by the MHRD aims to universalise education at the secondary level by 2016 - 17. This calls for additional preparation for teachers and teacher educators.

\section{Private Sector in Teacher Education Programme}

To meet up the crisis a large number of initiatives have been taken by private sectors. Their presence is urban dominated and market driven. Though the private sector helps in expanding the capacity for training teachers it is characterized by imbalances leaving much gap for the regional disparities. The proliferation and mushrooming of self financing institutions granted recognition by the NCTE for various teacher education courses has raised serious doubts about the teaching and training capacity available in these institutions and quality of courses transacted by them. The position of courses recognized by the NCTE on all India basis is shown below: Course-wise recognition granted by NCTE upto 31.07.2011

\begin{tabular}{|l|r|r|r|r|r|} 
Course & $\begin{array}{l}\text { No. of } \\
\text { Govt. } \\
\text { institutions }\end{array}$ & $\begin{array}{l}\text { Approved } \\
\text { intake }\end{array}$ & $\begin{array}{l}\text { No. of private } \\
\text { institutions }\end{array}$ & $\begin{array}{l}\text { Approved } \\
\text { Intake }\end{array}$ & $\begin{array}{l}\text { Total Intake } \\
\text { (Govt. + pvt.) }\end{array}$ \\
\hline $\begin{array}{l}\text { Elementary } \\
\text { (D.Ed.) }\end{array}$ & 757 & 49,089 & 4,831 & $2,98,278$ & $3,47,367$ \\
\hline $\begin{array}{l}\text { secondary } \\
\text { (B.Ed.) }\end{array}$ & 224 & 20031 & 5,730 & $6,09,486$ & $6,29,517$ \\
\hline M.Ed. & 102 & 3672 & 790 & 25,285 & 28,957 \\
\hline B.P.E.D. & 19 & 1284 & 538 & 28,150 & 29,434 \\
\hline Others & 76 & 16760 & 800 & 51,422 & 68,182 \\
\hline Total & 1178 & 90836 & 12,689 & $10,12,621$ & $11,03,457$ \\
\hline
\end{tabular}

\section{Rationale for Public Private Partnership}

The availability of government aided and self financing institutional capacity for teacher preparation varies across states .States such as Andhra Pradesh,Delhi,Gujarat,Haryana,Himachal,Karnataka,Kerala,MadhyaPradesh,Maharashtra,Punjab,Raja sthan,Tamil Nadu and Uttarakhand have low percentage of untrained teachers and sufficient capacity to prepare teachers in respect of demand for teachers. Whereas states like Assam,Bihar,Jharkhand ,Orissa , Chattisgarh , Jammu and Kashmir, Uttar Pradesh and West Bengal have high percentage of untrained teachers and low teacher preparation capacity as evident from the following table: 


\begin{tabular}{|l|rr|r|r|r|}
\hline State & \multicolumn{2}{|c|}{$\begin{array}{c}\text { Untrained } \\
\text { teachers }\end{array}$} & $\begin{array}{c}\text { Annual } \\
\text { D.Ed } \\
\text { Capacity }\end{array}$ & $\begin{array}{c}\text { Annual B.Ed } \\
\text { capacity }\end{array}$ & \multicolumn{1}{c|}{$\begin{array}{c}\text { Teacher } \\
\text { Vacancy }\end{array}$} \\
\hline Assam & $8,758(11.43 \%)$ & 1,320 & 4,310 & 42,550 \\
\hline Bihar & $1,73,167(51.51 \%)$ & 2,000 & 6,210 & $2,62,351$ \\
\hline Chhattisgarh & $33,714(29.98$ & 2,070 & 10,280 & 62,466 \\
& $\%(3,281(54.50 \%)$ & 1,460 & 5,550 & 43,839 \\
\hline Jharkhand & $33,401(17.64 \%)$ & 3,290 & 1,775 & 25,138 \\
\hline Orissa & $1,36,088(27.29 \%)$ & 18,775 & 1,22900 & $3,12,222$ \\
\hline Uttar Pradesh & $1,68,138(40.50 \%)$ & 4,180 & 13,505 & $1,80,945$ \\
\hline West Bengal & & & &
\end{tabular}

With this backdrop and increasing demand for teachers , there is a need for developing understanding of public private partnership in teacher education . Public private partnership is an approach under which services are delivered by the private sector, while the responsibilities for providing the resources rest with the government . Public private partnership is formed to bring together a set of action for common goal based on shared roles and principles. It is the form of agreement that entails reciprocal obligations and mutual accountability, the sharing of investment and reputation risks and joint responsibilities for administratives and executives. Public private partnership is being encouraged in view of the former's inability to meet the requirement duo inadequate resources and poor management. For the reformation of the teacher education in India the public private partnership in teacher education should focus on :

- Providing pre service and in service training to a large number of teachers without compromising with quality.

- Strengthening District Institutes of Education and Training (DIETs) and Colleges of Teacher Education (CTEs).

- Improving quality through ICT.

- Teacher capacity building.

\section{Public Private Partnership in Teacher Education}

"PPP is often described as a private investment where 2 parties comprising government as well as a private sector undertaking form a partnership" Ministry of Finance, Government of India.

"A risk-sharing relationship based upon an agreed aspiration between the public and private (including voluntary) sectors to bring about a desired public policy outcome. More often than not, this takes the form of a long-term and flexible relationship, usually underpinned by contract, for the delivery of public funded service." -Commission of UK PPPS

"A cooperative venture between the public and private sectors, built on the expertise of each partner that best meets clearly defined public needs through the appropriate allocation of resources, risks and rewards". - Canadian Council of PPPs

There are different models for Public Private Partnership in Teacher Education as follows:

- Joint Venture Model Private sector forms a joint venture company along with the government where private sector is responsible for investment in construction and management of the operations while government contributes by way of fixed assets at a predetermined value, whether it is land, buildings or facilities or it may contribute to the share holding capital.

- Management Contract Model Private sector invests in infrastructure and runs operations and management and the government takes the responsibility to pay the private investor for specified services. 
- Equity Model The government and private sector both invest in infrastructure and the management operations are done by private investors.

- Annuity Model The private sector invests in the infrastructure and the government runs the operations and management of the institutions in turn making annualised payments to private investor.

\section{Conclusion}

Public private participation in teacher education can work successfully following the recommended measures:

- Building trust as core value between the public and private sector.

- Negotiating a fair deal structure.

- Securing consistent and coordinating leadership.

- Designing transparent management system.

- Establishing an accreditation ensuring quality teacher education

However, following the RTE, clearing the Teacher Eligibility Test, 2010 is now part of the minimum qualifications for becoming teachers. Notwithstanding this, huge challenges of up gradation of teacher qualifications remain.

\section{References}

1. Education International (2009) Public-Private Partnerships in Education, Brussels: Education

2. Inclusive and Qualitative Expansion of Higher Education 12th Five Year Plan 20122017.

3. Muralidharan, K. (2006) Public-private partnerships for quality education in India, [Electronic],Available:

http://www.dise.in/Downloads/Use\%20of\%20Dise\%20Data/Karthik\%20Muralidhan.pdf

4. P. Jegadish Gandhi and M.L. Joseph (ed.), Public Private Partnership in Nation Building, Deep and Deep Publishers Pvt. Ltd., New Delhi, 2005

5. Report of the Working Group on Teacher Education for the 12th Five Year Plan.

6. Restructuring and Reorganization of the Centrally Sponsored Scheme on Teacher Education 2012. 